\title{
Factor Analysis of Metacarpal Bones
}

\author{
Sanae $\mathrm{KANDA}^{1)}$ and Eiki IKOMA ${ }^{2)}$ \\ 1) Department of Anatomy, Hyogo College of Medicine, \\ Nishinomiya, Japan, 663. \\ 2) Department of Anatomy, Wakayama Prefectural Medical College, \\ Wakayama, Japan 640.
}

\begin{abstract}
Measurement on metacarpal roentgenograms of male adult Japanese $(n=62)$ and direct measurements on metacarpal bones $(n=33)$ were studied by the factor analysis. Analysis of measurements on roentgenograms and statures indicated the factorial independencies of the length, breadth, medullary diameter and ratio of the second metacarpal length to the fourth length (II/IV). The metacarpal breadth showed positive relations with the cortical thickness and cortical area, and the relative amount of cortex in the cross-sectional area showed a negative relation with the medullary diameter. The length of metacarpals was interpreted by the factor of tubular bone, including the stature. Metacarpal and medullary diameters were controlled by a common factor in a feeble way. Analysis of breadths and anteroposterior diameters of metacarpal bones showed that high loadings of each metacarpal appear in one or two factors, i.e., one factor controls the breadth and anteroposterior diameter of one metacarpal. Five metacarpal breadths are independent of each other, analytically.
\end{abstract}

As previously reported, patients with Down's syndrome show metacarpal shortenings and those with Holt-ORAM's syndrome show elongations in length (PoZNANSKI et al., '70). In other words, lengths of the tubular bones are controlled by genetical factors to a certain extent. Although research on breadth of metacarpals has progressed more slowly than that on length, PARK ('78) reported that metacarpal breadths are significantly below normal in TURNeR's syndrome. GARN et al. ('72) stated that "the hand skeleton is dimensionally complex, and even the most experienced student of the hand cannot hold in mind the dimensional relationships of hand bones." Hrmes et al.
('76) analysed the relationships between body sizes and second metacarpal dimensions by means of the correlation and the regression analysis, showing that body size has marked correlations with the length, cortical thickness and cortical area of the second metacarpal. On the other hand, applications of multivariate data analysis on anthropological research are the most important problems for processings of scientific data. Most frequently, the factor analysis has been applied to studies of physical anthropology since the report of THURSTONE ('47) and its use has progressed in anthropological fields. An attempt to apply the factor analysis on the measurements of metacarpals is 
described in this paper.

\section{MATERIALS AND METHODS}

In the first step of the analysis, the materials used were the left hands of sixty two Japanese male medical students (21. 73 years in average, $\mathrm{SD}=0.96$ ). Hands of participants were placed on cassettes and radiographs taken at a focal distance of $100 \mathrm{~cm}$. The lengths of metacarpals were measured on films along the longest axes of five metacarpals. Breadths (B) and medullary diameters (MD) were measured at the midshaft points of axes. Measurements were carried out by calipers to the nearest $0.1 \mathrm{~mm}$. Cortical thickness (CT) was obtained by subtraction of the medullary diameter from the breadth. Crosssectional cortical area (CA) was estimated as $\mathrm{CA}=0.785\left(\mathrm{~B}^{2}-\mathrm{MD}^{2}\right)$. Relative amount of cortex in cross-sectional area was estimated as $\mathrm{PCA}=\left(\mathrm{B}^{2}-\mathrm{MD}^{2}\right) / \mathrm{B}^{2} \times 100$. Proportion of the second metacarpal length relative to the fourth length (II/IV) was calculated. Analysis was applied to the above mentioned measurements, ages and statures of the participants. Thirty three items in all were analysed.

In the second step of the data analysis, measurements were made on the breadths and posteroanterior diameters (thicknesses) at midshaft points of metacarpal bones of left hands. The metacarpal bones were composed of sexually undetermined 33 bodies and their racial source was obscure. Since first and fifth metacarpals show pronational or supinational positions in living hands, it is necessary to evaluate the possible extent of contributions of metacarpal breadths and thicknesses on roentgenographical diameters. So, radial faces of the first metacarpals and the palmar faces of the fifth metacarpals were fixed on the cassettes and photographed. Further roentgenograms included posteroanterior images of the first metacarpals of which ulnar sides of proximal portions were lifted as high as $2 \mathrm{~mm}$ by insertion of a plate. Breadths of metacarpal roentgenograms were measured at midshaft points of the long axes. These thirteen items were then analysed factorially.

Data was initially computed by the principal component analysis and treated with the varimax rotation method. Measurements whose loadings were above 0.40 in absolute values were used for interpretations of factors.

\section{RESULTS}

The first analysis: Ten factors were extracted from thirty three items (Table 1 ). In the first factor, positive loadings were found in the third and fourth MD and negative loadings in the third and fourth $\mathrm{CT}$ and PCA. The first factor might be referable to the third and fourth MD. In the second factor, positive loadings were found in the second, third, fourth and fifth breadths and CA, and in the third and fourth CT. Therefore, this factor might be referred to the second, third, fourth and fifth metacarpal breadths. The third factor had positive loadings in five metacarpal lengths and stature and might refer to lengths of tubular bones.

In the fourth factor, a positive loading 
Table 1. Factor loadings of measurements on roentgenograms*.

\begin{tabular}{|c|c|c|c|c|c|c|c|c|c|c|c|}
\hline \multicolumn{12}{|c|}{ Male Students } \\
\hline & & I & II & III & IV & $\mathrm{V}$ & $\mathrm{VI}$ & VII & VIII & IX & $\mathrm{X}$ \\
\hline \multicolumn{2}{|l|}{ Age } & -04 & -01 & 04 & -12 & -10 & -09 & -03 & 03 & -05 & -96 \\
\hline \multirow{6}{*}{$\begin{array}{l}\text { Stature } \\
\text { Length of } \\
\text { metacarpal }\end{array}$} & & 08 & 26 & 81 & 00 & 09 & 03 & 14 & 03 & 07 & -05 \\
\hline & $I$ & 14 & 14 & 80 & 12 & 28 & 18 & 02 & 05 & 06 & -00 \\
\hline & II & 09 & 14 & 96 & 04 & 04 & 04 & 08 & 02 & 01 & 00 \\
\hline & III & 05 & 08 & 95 & 07 & 11 & 07 & -12 & 02 & 02 & 02 \\
\hline & IV & 07 & 13 & 93 & 08 & 05 & 03 & -27 & 01 & 04 & -02 \\
\hline & $\mathrm{V}$ & 06 & 16 & 90 & 05 & 02 & 07 & -25 & -00 & 00 & 01 \\
\hline \multirow{5}{*}{$\begin{array}{l}\text { Breadth of } \\
\text { metacarpal }\end{array}$} & $I$ & 27 & 28 & 20 & 15 & 19 & 71 & -04 & 14 & 45 & 08 \\
\hline & II & -02 & 50 & 14 & 09 & 29 & 20 & 01 & 75 & 04 & 00 \\
\hline & III & 18 & 82 & 22 & 05 & 27 & -07 & 01 & 22 & 11 & 03 \\
\hline & IV & 14 & 85 & 23 & 09 & -08 & 21 & -00 & 19 & 05 & 04 \\
\hline & $\mathrm{V}$ & 24 & 75 & 15 & 24 & 09 & 36 & 11 & -05 & 13 & -02 \\
\hline \multirow{4}{*}{$\begin{array}{l}\text { Medullary } \\
\text { diameter }\end{array}$} & $I$ & 34 & 13 & 14 & 28 & 20 & 34 & -06 & 06 & 77 & 06 \\
\hline & II & 30 & 21 & 26 & 25 & 77 & 16 & -04 & 24 & 18 & 06 \\
\hline & III & 83 & 27 & 21 & 03 & 32 & 01 & -07 & 02 & 18 & 08 \\
\hline & IV & 75 & 35 & 15 & 37 & 02 & 16 & 11 & 05 & 19 & 00 \\
\hline \multirow{6}{*}{$\begin{array}{l}\text { Cortical } \\
\text { thickness }\end{array}$} & $\mathrm{V}$ & 30 & 35 & 18 & 76 & 21 & 14 & -02 & -02 & 29 & 06 \\
\hline & $I$ & -23 & 19 & 06 & -28 & -08 & 47 & 06 & 11 & -75 & 01 \\
\hline & III & -39 & 24 & -19 & -22 & -67 & $-\infty$ & 06 & 44 & -18 & -07 \\
\hline & III & -79 & 49 & -03 & 01 & -11 & -07 & 10 & 19 & -10 & -06 \\
\hline & IV & -67 & 51 & 08 & -31 & -11 & 05 & -13 & 14 & -15 & 03 \\
\hline & $\mathrm{V}$ & -12 & 39 & -06 & -75 & -19 & 22 & 16 & -03 & -25 & -11 \\
\hline \multirow[t]{5}{*}{$\mathrm{CA}$} & $I$ & 06 & 31 & 20 & -08 & 10 & 86 & 01 & 17 & -17 & 10 \\
\hline & II & -20 & 50 & -00 & -05 & -13 & 16 & 03 & 80 & -04 & -05 \\
\hline & III & -24 & 85 & 18 & 05 & 16 & -11 & 05 & 27 & 04 & 00 \\
\hline & IV & -14 & 84 & 20 & -04 & -10 & 17 & -04 & 20 & -02 & 07 \\
\hline & $\mathrm{V}$ & 09 & 74 & 14 & -15 & -02 & 30 & -11 & -05 & -23 & -12 \\
\hline \multirow[t]{5}{*}{ P C A } & $I$ & -34 & 00 & -06 & -31 & -17 & 02 & 05 & 01 & -86 & -04 \\
\hline & II & -35 & -08 & -25 & -26 & -81 & -11 & 05 & -03 & -17 & -09 \\
\hline & III & -89 & -02 & -14 & -01 & -27 & -04 & 09 & 07 & -17 & -06 \\
\hline & IV & -83 & -07 & -10 & -39 & -06 & -08 & -14 & 01 & -20 & 09 \\
\hline & V & -26 & -11 & -15 & -85 & -21 & -03 & 07 & 00 & -30 & -08 \\
\hline \multicolumn{2}{|l|}{$\begin{array}{l}\text { Relative length } \\
\text { of II/IV }\end{array}$} & 02 & 00 & -26 & -12 & -07 & 00 & 92 & 03 & -10 & 04 \\
\hline
\end{tabular}

*decimals are omitted.

was found in the fifth MD and two nega- might be referable to the fifth and second tive loadings in the fifth CT and PCA, MD respectively as well as to an interand the fifth factor showed a positive pretation of the first factor.

loading in the second $\mathrm{MD}$ and two nega- In the sixth factor, positive loadings tive loadings in the second CT and PCA. were found in the first breadth, CT and Therefore, the fourth and fifth factors CA. And might be referred to the breadth 
Table 2. Factor loadings of measurements of metacarpal skeletons****.

\begin{tabular}{|c|c|c|c|c|c|c|c|c|c|}
\hline & & & $\mathrm{I}$ & II & III & IV & V & VI & VII \\
\hline 1 & $I$ & breadth & 47 & 03 & -14 & 03 & 02 & -03 & 83 \\
\hline 2 & $\mathrm{I}$ & thickness & 79 & -01 & 17 & -28 & -22 & 36 & 21 \\
\hline 3 & III & breadth & -03 & 10 & -07 & 89 & -04 & 03 & 27 \\
\hline 4 & II & thickness & -09 & -10 & 12 & 86 & 23 & 11 & -30 \\
\hline 5 & III & breadth & -05 & -07 & 96 & 01 & -03 & 03 & -01 \\
\hline 6 & III & thickness & 03 & 08 & 94 & 01 & 16 & -03 & -09 \\
\hline 7 & IV & breadth & 15 & 21 & -01 & 21 & 45 & 78 & $-0 \overline{5}$ \\
\hline 8 & IV & thickness & 03 & 06 & 12 & 09 & 94 & 18 & 01 \\
\hline 9 & V & breadth & -13 & 90 & -03 & 00 & -02 & 10 & 15 \\
\hline 10 & $\mathrm{~V}$ & thickness & 10 & 91 & 11 & 05 & 16 & -05 & 13 \\
\hline 11 & $I$ & thickness* & 92 & -05 & -11 & -15 & 06 & 16 & 08 \\
\hline 12 & $I$ & breadth** & 83 & 02 & 00 & 26 & 17 & -30 & 21 \\
\hline 13 & V & thickness*** & 00 & 84 & -09 & -03 & -02 & 14 & -35 \\
\hline
\end{tabular}

* measurement of roentgenogram on which radial face of I metacarpal is fixed.

** posteroanterior roentgenogram of I metacarpal of which ulnar side of proximal portion is lifted as high as $2 \mathrm{~mm}$.

*** measurement of roentgenogram on which palmar face of $\mathrm{V}$ metacarpal is fixed.

**** decimals are omitted.

of the first metacarpal. The seventh factor had a loading in the proportion of the second length relative to the fourth metacarpal length.

The eighth factor showed positive loadings in the second breadth, CT and CA, and might be referable to the second metacarpal breadth.

In the ninth factor, positive loadings were found in the first breadth and MD, and the negative loadings in the first CT and PCA. Therefore, the factor might be referred to the first $\mathrm{MD}$ as well as to an interpretation of the first factor.

The tenth factor had a loading in age. The age may be independent of the adult metacarpal measurements.

The above mentioned interpretations may be adjusted as follows: all metacarpal lengths can be interpreted by a single factor; metacarpal breadths share positive loadings with the $\mathrm{CT}$ and $\mathrm{CA}$ in a factor, although the first and second breadths have the loadings in several factors; and high loadings of MD are found in four factors. Therefore, MD shows a more complicated factorial nature than the breadths and reveals reverse correlations to CT and PCA factorially.

The second analysis: In the first step of the analysis, the complexity of the factorial pattern of the metacarpal breadths was indicated and therefore, in this step, direct measurements of breadths and thicknesses of metacarpal bones are analysed. The analysis extracts seven fac- 
tors from thirteen items (Table 2).

The first factor had high loadings in four measurements of the first metacarpal, and might be referred to the first metacarpal.

Applying the same interpretation to the second to seventh factors, these might be referable to the fifth, third, second, fourth, fourth and first metacarpals. One factor had high loadings in one metacarpal, so one factor corresponds with one metacarpal. The first and fourth breadths showed high loadings in two factors and breadths revealed more complexity than metacarpal lengths. In this analysis, a common factor which controls plural metacarpal breadths was not revealed as in the first analysis.

\section{DISCUSSIONS}

The Japanese metacarpals revealed increases of their breadths and CT according to the body growth, but MD showed no increase (KIMURA, '76). On the other hand, HoRsMAN et al. ('75) reported that decreases of cortical thicknesses of menopausal women are caused by increases of $\mathrm{MD}$, and metacarpal breadths do not change after the menopause. Therefore, CT associates positively with metacarpal breadth and negatively with MD. The metacarpal breadths and MDs changed their diameters independently. Studies of correlation coefficients between body size and metacarpal measurements by YARBROUGH et al. ('77) concluded that "for given stature, chronological age is positively associated with cortical thickness and cortical area and negatively associated with periosteal and medullary diameter". Results of the above mentioned metrical researches coincide with the interpretation of distribution of signs of factor loadings in a factor.

Correlation analysis was made on stature, weight, metacarpal length, MD, CT, CA and PCA by Himes et al. ('76) but did not describe the natures of metacarpal breadth. The present analysis describes the independence of one metacarpal breadth from the others.

GARN et al. ('75) studied bone-to-bone ratios of metacarpals and stated that "fetal bone-to-bone ratios also show reasonable correspondence to adult bone-to-bone ratios". That is to say, bone-to-bone ratios are almost constant throughout the growing period. In the present report, the proportion of the second metacarpal length relative to the fourth length (II/IV) showed a high loading in one factor, indicating that the proportion has a peculiar nature in relation to other measurements.

\section{REFERENCES}

Garn, S. M., K.P. Hertzog, A.K. Poznanski and J.M. NAGY, 1972: Metacarpophalangeal length in the evaluation of skeletal malformation. Pediatric Radiology, 105: 375-381.

GARN, S. M., A.L. Burdi, W. J. BABler and S. STINSON, 1975: Early prenatal attainment of adult metacarpal-phalangeal rankings and proportions. Am. J.Phys. Anthrop., 43: 327332.

Himes, J. M., R. M. MAlina and C. D.Stepick, 1976: Relationships between body size and second metacarpal dimensions in Oaxaca (Mexico) school children 6 to 14 years of age. Human Biol., 48: 677-692.

Horsman, A. and M. Simpson, 1975: The measurement of sequential changes in cortical 
bone geometry. Br. J. Radiol., 48: 471-476.

KIMURA, K., 1976: Growth of cortical thickness of the second metacarpal in Japanese. Acta Anat. Nippon., 51 : 89-95.

PARK, E., 1978: Cortical bone measurements in TURner's Syndrome. Am. J. Phys. Anthrop., 46: 455-462.

Poznanski, A.K., Jr.J.C. Gall and A.M. STERN, 1970: Skeletal manifestations of the Holt-Oram Syndrome. Radiology, 94: 45-53.
THURSTONE, L. L., 1947 : Factor analysis of body measurements. Am. J. Phys. Anthrop., 5: 1528.

Yarbrough, C., R. Martorell, R.E. Klein, J. Himes, R. M. Malina and J-P. Habicht, 1977: Structure and age as factors in the growth of second metacarpal cortical bone in moderately malnourished children. Ann. Hum. Biol., 4: 43-48.

(Received July 13, 1979)

中手骨の因子分析による研究

\section{欠田早苗 ${ }^{1)}$ ・生駒栄喜 ${ }^{2)}$ \\ 1) 兵庫医科大学解剖学教室 \\ 2) 和歌山医科大学解剖学教室}

日本人成人男性の左中手骨のレントゲン像 $(n=62)$ より長径, 幅径 (B) および骨髄幅 (MD) を計測し, それらより皮質面積 $\left(\mathrm{CA}=0.785\left(\mathrm{~B}^{2}-\mathrm{MD}^{2}\right)\right)$ ，皮質面皘の比例值 $\left(\mathrm{PCA}=\left(\mathrm{B}^{2}-\mathrm{MD}^{2}\right) / \mathrm{B}^{2} \times 100\right)$ ならびに 第 2 指長の第 4 指長に対する比を求めて因子分析にかけた。その結果，すべての中手骨の長径は身長をも含め て，ひとつの因子で説明できるが，幅径については第 $1 ， 2$ および 5 指の高い負荷量が複数の因子に分散して いて，因子的に複雑な性質を予想しうる。

ついで，左中手骨の晒骨標本について，幅径と前後径（厚み）を計測し，また第 1 と 5 指のレントゲン像で の幅径を加えて分析した。その結果, 各指の幅径と前後径は同一の因子の支配を受け, 各指の幅径の因子は互 いに独立性が明確で, 幅径の複雑性が指摘されうる。 